\title{
Microsavings Mobilization Innovations and Poverty Alleviation in Nigeria
}

\author{
Babajide Abiola A. (Ph.D) \\ Corresponding Author, Department of Banking and Finance, Covenant University, Ota, P.M.B 1023, Ota, Ogun State, Nigeria \\ Email: abiola.babajide@covenantuniversity.edu.ng, abiolababajide@gmail.com \\ Taiwo Joseph N (Ph.D) \\ Department of Banking and Finance, Covenant University, Ota, P.M.B 1023, Ota, Ogun State, Nigeria \\ Email: joseph.taiwo@covenantuniversity.edu.ng \\ Isibor John A \\ Department of Banking and Finance, Covenant University, Ota, P.M.B 1023, Ota, Ogun State, Nigeria \\ Email: areghan.isibor@covenantuniversity.edu.ng
}

\section{Doi:10.5901/mjss.2015.v6n4p375}

\section{Abstract}

Innovation in microfinance is given as any change in banking technology which resulted in improved viability and/or outreach of the microfinance institution. This paper examined the influence of innovative savings products in the Nigerian banking industry on welfare and business enterprise development of low-income earners and self-employed individuals in Nigeria. The paper employs primary data from a structured questionnaire and uses ordinary least squares to test study hypotheses. The results obtained show that the savings rate has increased by $160 \%$ since the introduction of the innovative savings account. The study therefore recommends more awareness programs on innovative savings products. Résumé L'innovation dans le secteur de la microfinance est caractérisée par des changements dans la technologie bancaire, qui ont permis une amélioration de la viabilité et/ou du rayonnement de l'institution de microfinance. Ce document examine l'influence des produits d'épargne novateurs dans l'industrie bancaire nigériane sur le welfare et le et développement des affaires des salariés à faibles revenus et des travailleurs autonomes au Nigéria. Le document utilise des données primaires à partir d'un questionnaire structuré et la méthode des moindres carrés ordinaires pour tester des hypothèses de l'étude. Les résultats obtenus montrent que le taux d'épargne a augmenté de $160 \%$ depuis l'introduction du nouveau compte d'épargne. L'étude recommande donc davantage de programmes de sensibilisation pour ce type de produits d'épargne.

Keywords: Microsavings, innovation, poverty alleviation, savings products, Nigeria.

\section{Introduction}

Microsavings is an aspect of microfinance consisting of a small deposit account offered to low-income families or individuals as an incentive to store funds for future use. Microsavings accounts work in a way similar to a normal savings account; however, they are designed around smaller amounts of money. The minimum balance requirements for opening a bank account are often ignored, or very low to allow account holders to save small amounts of money and not necessarily pay for the service. Microsavings are commonly offered in most developing countries to help low-income earners save for future investment or cope better in case of unforeseen circumstances.

Savings are critical to households in developing countries where aggregate savings are very low. By saving regularly, poor people are more prepared to deal with basic issues that often overwhelm them. Typically savings mobilization is considered low in developing countries. Low savings might be a consequence of poor access to safe, flexible, convenient, and affordable savings products.

Savings are very important in the development process of any nation. The importance of savings in developing economies can be discussed from two main perspectives. The first relates to the resource gap which needs to be bridged through enhancing a savings culture amongst the population. As a result of low per capita income, most developing countries have low savings rates compared to countries in advanced economies and this has affected the level of capital formation in those countries. The second is to ensure financial inclusion for all in the economy. The reason is that the provision of financial services is an important means for mobilizing resources for more productive use (Watson and Everett, 1999).

In many developing countries, more capital is held in the informal economy than in the formal one. A large part of this capital is held in small amounts by those living near or below the poverty line (Sanusi, 2002). Developing countries 
can bring these numerous small capital holdings into the formal sector by providing poor households with savings services that can meet their needs and made readily accessible to them. This assertion provides the impetus for the establishment of microfinance institutions (MFIs), so that access to savings services could be enhanced. Crosscountry experiences in Africa, Asia and Latin America have shown that savings can be harnessed from the poor given the right institutional arrangements and efforts at reaching the population with innovative products that meet their needs.

Innovations in microfinance can take the form of new products or services developed by a MFI for poor clients at the least cost possible. It could be a new way of screening and lending to clients that overcomes problems of information asymmetry or it could be a product that meets the risk-management requirement of poor people (e.g. micro-insurance), or that enables the poor to smooth their consumption and create financial assets by themselves (e.g. microsavings). Innovative products and services could thus increase the overall impact of microfinance on poverty reduction (Ashraf, Gons, Kalan and Yin, 2003).

Microsavings can be used as a poverty reduction strategy. According to the Organisation of Economic Cooperation and Development (OECD), poverty reduction (or poverty alleviation) is any process that seeks to reduce the level of poverty in a community, or amongst a group of people or countries. Poverty reduction programmes may be aimed at economic or non-economic poverty. Some of the popular methods used are education, economic development, and income redistribution. Poverty reduction efforts may also be aimed at removing social and legal barriers to income growth among the poor. For poverty reduction initiatives to succeed the beneficiaries must be empowered and made to contribute to the wealth creation process through their involvement in viable business or trade, and for such business to thrive the micro-entrepreneur needs to save.

This paper examined some of the innovative savings products introduced into the Nigerian financial system to encourage poor people to save. Some of the savings products investigated are E-susu introduced by Stanbic IBTC, Firstlnstant by First Bank Nigeria PIc, Finaflex and FTAP introduced by Fina Trust Microfinance Bank, Amanah Savings introduced by Mainstreet Microfinance Bank, AB savings by AB Microfinance Bank, Asset Special Savings (ASSA) by Assets Microfinance Bank Ltd., Vineland Target Microsavings (Kolo) by Vineland Microfinance Bank, LAVTSA by Lavender Microfinance Bank, and GT e-account and Xmas Business Savings by LAPO. The savings products have innovative features such a commitment savings, mobile money collection, ability to access the account through bigger partnering banks all-over the nation, waiver of opening cash, minimum balance as low as N200 (US\$1), and ATM card advantage that makes it easier to transact business through any compatible ATM machine.

Several studies on savings mobilization in rural areas of Nigeria are in existence, but a study on microsavings mobilization innovation impact analysis is rare in Nigeria. This paper, therefore, attempts to fill this gap. This study identifies the innovative microsavings products available within the Nigerian financial system and analyses their impact on household poverty using regression analysis. This is the overall objective of this study. The specific objectives are to: (i) ascertain if savings rate changes are the result of the introduction of a savings product, (ii) evaluate the impact of the savings product on household well-being variables, and (iii) analyse the impact on microenterprise development. In order to achieve the above stated objectives, the following null hypotheses are proposed and tested in the course of this study: (i) the savings rate has not changed significantly after the introduction of innovative savings products in the Nigerian financial system; (ii) there is no significant reduction in the level of household poverty in Nigeria as a result of the introduction of innovative savings products; and (iii) innovative savings products do not significantly impact microenterprise development in Nigeria. The rest of the paper is divided into four sections. In section II, relevant theory and literature are reviewed, while the methodology of the study is explained in section III. The findings and discussion of results are presented in section IV, while section $\mathrm{V}$ contains the concluding remarks.

\section{Theoretical Framework and Literature Review}

\subsection{Literature Review}

Classical economists as early as 1776 explained the importance of savings. Smith (1776) recognized the importance of savings when he observed, "Capital is increased by parsimony and diminished by prodigality and misconduct". Prior to 1936, classical economists propounded their theory on savings and asserted that a negative relationship existed between savings and interest rates. Keynes (1936) defined savings as the excess of income over expenditure on consumption. This means that savings are that part of disposable income of the period that is not yet consumed (Umoh, 2003; Uremadu, 2006). Given that income is equal to the value of current output, current investment (i.e. gross capital formation) is equal to the value of that part of current output that is not consumed; savings are therefore equal to the excess of income over consumption. Savings are fundamentally about choosing between current and future consumption. 
Savings theories traditionally predict that current consumption is related not to current income, but to a longer-term estimate of income.

Traditional models of savings, such as the life-cycle hypothesis (Modigliani, 1966) and the permanent income hypothesis (Friedman, 1954) assume that individuals exponentially discount consumption to determine how much to save for future consumption versus current consumption. The life-cycle hypothesis (Modigliani, 1966) predicts that individuals hold their consumption constant over their lifetime: they save during their working years and draw down their savings during retirement. The permanent income hypothesis (Friedman, 1954) argues that consumption is proportional to a consumer's estimate of permanent income. These theories of savings were developed with industrial economies in mind. They do not really apply to the situation in developing economies. Deaton (1989) suggests at least four reasons why these two theories might be of limited use in developing nations. First, households in developing countries are larger than in industrialized countries and are more likely to contain several generations. As a result there is less need to save for retirement or for inter-generational transfers. Second, income in many of these economies is uncertain and cyclical, making estimation of longer-term income flows difficult. Third, individuals are likely to be credit constrained, so that borrowing in early years will be difficult. Finally, these combined factors suggest that savings in developing economies often play an important role in buffering between income and consumption. Individuals often save small amounts at frequent intervals to smooth income, rather than accumulate or save for retirement.

More recent theories on savings in use now are "hyperbolic discounting" and "mental accounting" (Lowenstein and Thaler, 1989; Thaler, 1990, 1992; Laibson, 1997; O'Donahue and Rabin, 1999). Hyperbolic discounting models suggest that individuals would improve their welfare by seeking mechanisms that commit them to save more for the future. Mental accounting theories suggest that individuals often behave as if money is not fungible, and hence savings levels can be affected by mere framing of decisions. Commitment mechanisms that bind an individual to future actions or restrict individual choice in the future can overcome these inconsistencies. Many financial institutions, particularly in developing countries, implicitly or explicitly should have these theories in mind when designing their savings products. Low savings in developing economies might be a consequence of merely poor access to safe, flexible, convenient, and affordable savings products.

Fasoranti (2007) examined rural savings mobilization on economic development of rural dwellers using multiple regression analysis. The result obtained shows that savings mobilization in rural areas is positively related to investment, asset acquisition, human development and personal income. Social economic variables will increase in rural areas if savings mobilization innovations with commitment characteristics through rural cooperative movement are encouraged among rural dwellers. Dupas and Robinson (2013) examined the impact of limited access to formal savings services on business growth in poor countries using non-interest-bearing bank accounts between two types of self-employed individuals in rural Kenya. They were able to establish that despite large withdrawal fees, substantial share of market women using the accounts were able to save more and increase their productive investment and private expenditures.

\subsection{Microfinance and Innovation}

Any changes in banking technology, types of financial services offered, strategic behaviour of the institution, institutional arrangement, or structure of incentives that result in improved viability and/or outreach of the MFI is referred to as innovation in microfinance (Lariviere and Martin, 1998). Five categories of innovation in rural microfinance are identified in the literature, and they are: technological innovations, product innovations, strategic innovations, institutional arrangement innovations, and donor incentive innovations. Technological innovation has to do with improved technologies used in delivering financial services. Product innovations are redesigning of financial service products offered to individuals and groups. Strategic innovations refer to strategies followed by MFIs to develop their clientele. Institutional arrangement innovations refer to changing legal status and the institutional arrangements to improve MFI performance. Donor incentive innovations refer to those mechanisms that are available to donors to improve the performance of MFIs (Lariviere and Martin, 1998).

Buchenau (1999) suggested a narrower characterization of innovations focusing on innovations in financial services only, which he categorized into two types: (i) completely new products that match the characteristics of intended users, and (ii) improvements or refinements in the procedures used in delivering services or to design contracts and enforce them. Agosin (1999), citing a study by McGuire and Conroy (1999), distinguishes three levels of financial innovation: (i) system innovation where new institutions tailored to deal with unmet needs are created or allowed to emerge, (ii) process innovation or the creation of new technologies for providing financial services, and (iii) product innovation or the supply of new financial products.

There is a need, particularly in developing economies to foster financial innovations in microfinance markets in 
developing economies in order to reach poorer members of society without endangering the viability of MFIs. This paper fills the gap in the literature by examining the impact of innovative savings products in the Nigerian financial system on welfare and enterprise development drive of the savers. The savings accounts investigated are:

a. E-susu by Stanbic IBTC - A unique blend of traditional banking practice and modern information technology. The product has features such as zero minimum opening balance, a simple account opening process, and easy account access for customers in any of the bank's branches.

b. The First-Instant savings product by First Bank PIc is designed for the unbanked and under-banked to enhance financial inclusion. Its unique features includes, minimum opening balance of $\mathrm{N} 1,000$, minimum operating balance of $\mathrm{N} 500$, simplified account opening form, mandatory issuance of debit card, regular savings interest rate applies, can also be opened as a salary account for low-income earners, operated primarily via alternative channels (e.g. POS, ATM, mobile phone, etc.), free e-mail alert, SMS alert at a fee, and restricted number of withdrawals in a month or forfeit interest.

c. GT e-account is a personal banking savings product that allows salary earners to carry out all banking transactions conveniently through all available e-channels. It is designed for low salary earners to be able to acquire any asset on easy terms in as much as there is proof of valid employment. The account also has commitment savings characteristics.

d. Fina Trust Microfinance Bank is a leading microfinance bank based in Lagos Nigeria. Its two products, Fina Advance Product (FTAP) and Finaflex savings account, can be accessed from any branch of Fidelity Bank Plc and Sterling Bank Plc with branches spread across all six geographical zones in Nigeria. The product has wider coverage. Sales / cash collector is attached to all clients.

e. Amanah savings product by Mainstreet Microfinance Bank is designed with MB Collect integrated. MB Collect is a robust web-based, in-branch solution that helps to effectively render customized collection service on behalf of organizations to their valued customers. With MB-Collect, savers can make payments at any Mainstreet Bank branch office nationwide. The product can be customized to the customer's specific requirements.

f. AB Savings Account by AB Microfinance Bank Nigeria gives the saver the advantages of competitive interest rates with commitment savings characteristics. The unique features are a minimum opening balance of NGN1,000 (\$6), simple account opening process, attractive interest rates, free statement of account (on request), transparent and speedy transactions, and withdrawals up to available balance in account at the desired target time.

g. Assets Special Savings Account (ASSA) is characterized by a minimum balance of NGN200 (\$1.1), commitment savings characteristics, interest rate of $7 \%$ p.a., ATM card, third party payment of cheques, and free quarterly statement of account.

h. LAVTSA by Lavender Microfinance Bank is an account that allows the individual to save for a target project, business or any achievements in life. Savings could be daily, weekly, monthly or anytime of the daily operations of the bank. It attracts higher interest at the end of the target period. It is time limit savings, e.g. savings of N5,000 for six months to purchase electronics; time limit of savings depends on customer agreements with the bank. Withdrawal is not allowed until the target day. Minimum balance: N500.

i. Vineland Target Micro Savings (Kolo Vineland) - This is a target account to encourage savings towards seasonal business/projects, e.g. Christmas, New Year, Easter sales or Ramadan sales, etc. Unique features are opening balance of N1000, minimum daily savings of N200, six-month duration to qualify for a loan, loan interest payable monthly, and interest payable monthly.

j. Xmas Business Savings Account (LAPO) - Is a commitment savings account that allows clients to begin amassing resources needed to stock inventory and successfully meet demand at Christmas. Withdrawal from the account is not allowed. The amount saved is variable based on clients' capacity.

\section{Research Methodology}

The study was carried out in Lagos and Ogun states, southwest Nigeria, covering both urban and rural areas of the two states. Lagos being the commercial nerve centre in Nigeria plays host to many specialty banks, as well as many informal financial service providers. Ogun State shares similar characteristics with Lagos because of its proximity to Lagos State. Data came from secondary and primary sources. The secondary sources include relevant textbooks and journal publications. Data from primary sources were collected using structured questionnaire. The information collected for the study includes savings rate before and after signing up for the innovative savings account, frequency of saving, amount 
saved, reasons for the change in amount and frequency (if any). Other information collected includes age measured in years, level of education measured in category, sex of the respondents, economic activity engaged in, location of business activity, source(s) of income, number of sources of income, average weekly income, family size measured by number of persons per household, level of indebtedness, housing quality, ownership of major household appliances and motor vehicles, state of children's education, expenditure on food, effectiveness in coping with shocks measured in scale of severity, enterprise revenues, fixed assets of enterprise, number of employees of enterprise, saver's control over resources and income within the household economic portfolio, saver's self-confidence, and saver's ability to deal with shocks and emergency.

The study targeted low-income economically productive members of society, which includes skilled artisans, hawkers/traders, business owners/self-employed, labourers, farmers, students, micro manufacturers, and others such as commercial motor cycle riders, popularly known as "okada riders", gatemen/security men, cab drivers, food vendors, petty traders, etc. The study employed a combination of sampling techniques in selecting the study areas and the respondents. First, a purposive sampling technique was used to identify those banks offering innovative savings products and they cut across both microfinance banks and a few commercial banks in Lagos and Ogun states, while respondents were randomly sampled in each of the banks. A total of 300 copies of the questionnaire were distributed, 267 copies of questionnaire were returned and used for analysis. The data collected were analysed using descriptive statistics such as tables and percentages. The hypotheses set for the study were analysed using paired sample t-test and ordinary least squares multiple regression analysis. The following models were specified for the study.

\subsection{Model Specification}

Three hypotheses were tested for this study. The first hypothesis was tested using paired sample t-test, while the second and third hypotheses were tested using multiple regression analysis of the ordinary least squares. Fasoranti (2007) in his article "The influence of rural savings mobilization on economic development of rural areas: A study of Akoko region in Ondo State in Nigeria" specified this model: $S=\beta_{0}+\beta_{1} y+\beta_{2} \mathrm{H}+\beta_{3} \mid+\beta_{4} A+U$

Where $S=$ Total Savings from Ajo, E-susu, Thrift/Cooperative; $Y=$ Savers Income; $H=$ Human Capital Development; I = Investment of Respondents; $A$ = Personal Assets while $\beta_{0}, \beta_{1}, \ldots \ldots \beta_{4}$ are parameters to be estimated; and $\mathrm{U}=$ Random Effect. The model was adapted and slightly modified for this study as stated below:

\section{Model 1}

$\Delta H Y=f(E-S u, F I, G T, M F B, S G R, L E, S Y, B L, H S, D L) \ldots \ldots \ldots \ldots \ldots \ldots . . . .11]$

In specific form, equation 1 transforms to equation 2.

$\Delta H Y=\beta_{0}+\beta_{1} e-S U+\beta_{2} F I+\beta_{3} G T+\beta_{4} B M F B S+\beta_{5} S G R+\beta_{6} L E+\beta_{7} S Y+\beta_{8} B L+\beta_{9} H S+\beta_{10} D L+U$

Where, $\Delta \mathrm{HY}=$ Change in Household Income.

E-Su = E-susu Savings Account

$\mathrm{FI}=$ First Instant Savings Account

$\mathrm{GT}=\mathrm{GT}$ e-account

MFB = Microfinance Banks Savings Account

SGR = Savings Growth Rate

$\mathrm{LE}=$ Level of Education (Secondary Education)

$S Y=$ Number of Sources of Income (2 or more)

$\mathrm{BL}=$ Business Location (Urban)

HS = Household Size (Less than 5)

$\mathrm{DL}=$ Reduced Debt Obligation

$\beta_{0}, \beta_{1}, \ldots \ldots B_{10}$ are parameters to be estimated, $U=$ Random Effect.

Model 1 tests the impact of innovative savings products on household poverty alleviation.

A priori: $\beta_{1}>0 ; \beta_{2}>0 ; \beta_{3}>0 ; \beta_{4}>0 ; \beta_{5}<0, \beta_{6}>0, \ldots \ldots \beta_{10}>0$

Model 2

IBR = $f(E-s u, F I, G T, M F B, S G R$, YE, FA, HY, BO)

In specific form, equation 3 transforms to equation 4 .

$I B R=\beta_{0}+\beta_{1} e-S U,+\beta_{2} F I+\beta_{3} G T+\beta_{4} B M F B S+\beta_{5} S G R+\beta_{6} Y E+\beta_{7} F A+\beta_{8} H Y+\beta_{9} B O+U$

Where, IBR = Increase in Business Revenue.

E-Su = E-susu Savings Account

$\mathrm{FI}=$ First Instant Savings Account

$\mathrm{GT}=\mathrm{GT}$ e-account 
MFB = Microfinance Banks Savings Account

SGR = Savings Growth Rate

$Y E=$ Years of Experience in Business

FA = Fixed Asset Acquired Recently

$\mathrm{HY}=$ Household Income

$\mathrm{BO}=$ Business Outlet

$\beta_{0}, \beta_{1}, \ldots \ldots . B_{9}$ are parameters to be estimated, $U=$ Random Effect.

Model 2 tests the impact of innovative savings products on business enterprise development proxy with increase in business revenue.

\subsection{Measurement of Explanatory Variables}

Table 1. Description of Variable - Model 1

\begin{tabular}{|c|c|c|c|c|}
\hline$S / N$ & Variable & Measurement & $\begin{array}{l}\text { Expected Sign } \\
\text { on impact }\end{array}$ & Aprori \\
\hline 1. & $\begin{array}{l}\Delta \mathrm{HY}=\text { Change in Household } \\
\text { Income } \\
\text { (Dependent variable) }\end{array}$ & $\begin{array}{l}\text { Calculated as difference in household income before and after opening the saving } \\
\text { account }\end{array}$ & & \\
\hline 2. & E-susu(E-su) & E-susu account type (E-susu $=1$, other type of account $=0$ ) & + & $\beta_{1>0}$ \\
\hline 3. & $\begin{array}{l}\text { First Instant Savings } \\
\text { Account (FI) }\end{array}$ & First Instant Savings Account $=1$, other type of account $=0$ & + & $\beta_{2>0}$ \\
\hline 4. & GT e-account (GT) & GT e-account $=1$, other type of account $=0$ & $\begin{array}{l}+ \\
+\end{array}$ & $\beta_{3>0}$ \\
\hline 5. & $\begin{array}{l}\text { Microfinance Banks Savings } \\
\text { Account products(MFB) }\end{array}$ & Microfinance Banks Savings Account products $=1$, other type $=0$ & + & $\beta_{4>0}$ \\
\hline 6. & Savings Growth Rate (SGR) & $\begin{array}{l}\text { SGR = Savings Growth Rate - Savings growth rate, which is calculated as changes in the } \\
\text { amount saved before the savings account was opened and amount saved now, which is } \\
\text { defined as } S G R=\left\{\left(\mathrm{S}_{t} / \mathrm{S}_{0}\right)^{1 / \mathrm{n}}-1\right\} \times 100 \text { where } \mathrm{S}_{t} \text { is the current amount saved weekly now, } \\
\mathrm{S}_{0} \text { is the base year amount saved weekly before the account was opened, } n \text { is the } \\
\text { number of years saved so far while GR is the annual rate of growth. }\end{array}$ & + & $\beta_{5}$ \\
\hline 7. & Level of Education (LE) & $\begin{array}{l}\mathrm{LE}=\text { Primary Education } 1, \text { other }=0 \text {; Secondary Education }=1, \text { other }=0 \text {; Higher } \\
\text { Education }=1 \text {, other }=0\end{array}$ & + & $\beta_{6}$ \\
\hline 8. & $\begin{array}{l}\text { Number of Sources of } \\
\text { Income (SY) }\end{array}$ & $S Y=$ Number of Sources of Income ( 2 or more $=1$, other $=0$ ) & + & $\beta_{7}$ \\
\hline 9. & Business Location (BL) & Business Location (Urban $=1$, other $=0$; rural $=1$, other $=0$ ) & + & $\beta_{8}$ \\
\hline 10. & Household Size (HS) & Household Size (Less than $5=1$, other $=0$; more than $5=1$, other 0 ) & - & $\beta_{9}$ \\
\hline 11. & Reduced Debt Obligation & Reduced Debt Obligation $=1$, otherwise $=0$ & + & $\beta_{10}$ \\
\hline
\end{tabular}

Source: Author's compilation (2013)

Table 2. Description of Variables - Model 2

\begin{tabular}{|c|c|c|c|c|}
\hline $\mathrm{S} / \mathrm{N}$ & Variable & Measurement & $\begin{array}{c}\text { Expected Sign } \\
\text { on impact }\end{array}$ & Aprori \\
\hline 1. & $\begin{array}{l}\text { Increase Business Revenue (IBR) } \\
\text { (Dependent variable) }\end{array}$ & $\begin{array}{l}\text { Calculated as difference in monthly business revenue before and after opening the } \\
\text { saving account }\end{array}$ & & \\
\hline 2. & E-susu(E-su) & E-susu account type (E-susu = 1, other type of account $=0$ ) & + & $\beta_{1>0}$ \\
\hline 3. & First Instant Savings Account (FI) & First Instant Savings Account $=1$, other type of account $=0$ & + & $\beta_{2>0}$ \\
\hline 4. & GT e-account (GT) & GT e-account $=1$, other type of account $=0$ & + & $\beta_{3>0}$ \\
\hline 5. & $\begin{array}{l}\text { Microfinance Banks Savings Account } \\
\text { products(MFB) }\end{array}$ & Microfinance Banks Savings Account products $=1$, other type $=0$ & + & $\beta_{4>0}$ \\
\hline 6. & Savings Growth Rate (SGR) & $\begin{array}{l}\text { SGR = Savings Growth Rate - Savings growth rate, which is calculated as changes } \\
\text { in the amount saved before the savings account was opened and amount saved } \\
\text { now, which is defined as } S G R=\left\{\left(S_{t} / S_{0}\right)^{1 / n}-1\right\} \times 100 \text { where } S_{t} \text { is the current amount } \\
\text { saved weekly now, } S_{0} \text { is the base year amount saved weekly before the account was } \\
\text { opened, } n \text { is the number of years saved so far while GR is the annual rate of growth. }\end{array}$ & + & $\beta_{5}$ \\
\hline 7. & Years of Experience (YE) & Years of Experience in Business = measured in actual number of years & + & $\overline{\beta_{6}}$ \\
\hline 8. & Fixed Asset Acquired recently (FA) & $\begin{array}{l}\text { Fixed Asset Acquired Recently for the business (if yes }=1 \text {, otherwise }=0 \text {, if no }=1 \text {, } \\
\text { otherwise = 0) }\end{array}$ & + & $\beta_{7}$ \\
\hline 9. & Household income (HY) & $\begin{array}{l}\text { (+) increased household Income since saving (If Yes }=1 \text {, otherwise } 0 \text {; if } \mathrm{No}=1 \text {, } \\
\text { otherwise 0) }\end{array}$ & + & $\beta_{8}$ \\
\hline 10. & Business Outlet (BO) & Business Outlet measured in actual numbers. & + & $\beta_{9}$ \\
\hline 11. & Reduced Debt Obligation & Reduced Debt Obligation $=1$, otherwise $=0$ & + & $\beta_{10}$ \\
\hline
\end{tabular}

Source: Author's compilation (2013) 


\section{Results and Discussion}

\subsection{Socio-Economic Profile of Respondents}

The socio economic characteristics of the respondents are presented in Table 3 below. Table 3 shows that females $(n=154 ; 57.6 \%)$ make use of the innovative savings account product more than the males. The majority of the respondents are female; this confirms the assertion that women are more likely to save small amounts than men. With respect to age distribution of respondents, the table also shows that $63(23.6 \%)$ of the respondents were within the age group 16-19 years, 115 (43.1\%) were within the age group 20-35 years, 74 (27.7\%) were within the age group 36-55 years of age, while $15(5.6 \%)$ were 56 years and older. The majority of the respondents were within the active economic age group of $20-55$ years, which represents $71 \%$ of the total respondents.

The results are also classified in terms of the respondents' level of formal educational acquired; this is because formal education has a way of alleviating poverty. From the survey, the result revealed that $39(14.6 \%)$ do not have formal education, $56(20.9 \%)$ had only basic primary education, 109 (40.8\%) have completed secondary school, 63 (23.5\%) had post-secondary education such as a Ordinary National Diploma (OND) / National Certificate of Education (NCE) degree and some have a Higher National Diploma. The relevance of this is to ensure that respondents sampled for this study are not only mature in age but also have the requisite educational qualification to be able to provide logical answers to the questions asked in the questionnaire.

Table 3. Socio-Economic Profile of Respondents

\begin{tabular}{|c|c|c|c|}
\hline Variables & Measuring Group & Frequency & Percentage (\%) \\
\hline \multirow[t]{3}{*}{ Gender } & Male & 113 & 42.3 \\
\hline & Female & 154 & 57.6 \\
\hline & Total & 267 & 100 \\
\hline \multirow[t]{5}{*}{ Age (years) } & $16-19$ yrs & 63 & 23.6 \\
\hline & $20-35$ yrs & 115 & 43.1 \\
\hline & $36-55$ yrs & 74 & 27.7 \\
\hline & 56 and older & 15 & 5.6 \\
\hline & Total & 267 & 100 \\
\hline \multirow[t]{5}{*}{ Education Level } & No formal education & 39 & 14.6 \\
\hline & Primary & 56 & 20.9 \\
\hline & Secondary & 109 & 40.8 \\
\hline & Post-Secondary & 63 & 23.6 \\
\hline & Total & 267 & 100 \\
\hline \multirow[t]{5}{*}{ Marital Status } & Single & 77 & 28.8 \\
\hline & Married & 125 & 46.8 \\
\hline & Divorced/Separated & 44 & 16.5 \\
\hline & Widowed & 21 & 7.9 \\
\hline & Total & 267 & 100 \\
\hline \multirow[t]{5}{*}{ Household Size } & Less than five & 76 & 28.4 \\
\hline & More than 5 but less than 10 & 128 & 47.9 \\
\hline & More than 10 but less than 15 & 41 & 15.3 \\
\hline & More than 15 & 22 & 8.2 \\
\hline & Total & 267 & 100 \\
\hline \multirow[t]{4}{*}{ Religion } & Christianity & 138 & 68.9 \\
\hline & Islam & 105 & 31.1 \\
\hline & Others & 24 & 8.9 \\
\hline & Total & 267 & 100 \\
\hline
\end{tabular}

Source: Researcher's analysis of field survey, 2013.

As indicated in Table 3 , the majority $(n=125 ; 46.8 \%)$ of respondents who used innovative savings products are married. Respondents who are single constitute $28.8 \%$, while $16.5 \%(n=44)$ and $7.9 \%(n=21)$ were divorced and widowed respectively. That the majority is married is an indication that the savers are adults and are saddled with the responsibility of maintaining their families, hence the need to avail themselves of all available opportunities to save in order to be able to help family members.

As shown in Table 3, many of the respondents have large households. Only $76(28.4 \%)$ have less than five individuals in their household, 128 (47.9\%) have more than five individuals but less than 10. Forty-one (15.3\%) have more than 10 but less than 15 individuals in their household, and $22(8.2 \%)$ have more than 15 individuals in their 
household. The implication of this large household size is obvious. When output increases due to improved technology and capital formation, the large population easily swallows it up, and the family tends to be in perpetual poverty except the majority of the members of the household are economically productive. Large family size usually attracts high expenditures and if not matched with adequate income poverty will continue in the family.

The results obtained on religion of respondents show that 138 (68.9\%) are Christians, 105 (31.1\%) are Muslims, while $24(8.9 \%)$ belong to another religion, probably a traditional religion.

\subsection{Savings Characteristic of Respondents}

Table 4 below shows that $62(23.2 \%)$ of the respondents had two to five years of working experience in their primary occupation, 105 (39.3\%) had 6-10 years of working experience, 55 (20.5) had 11-15 years of working experience, while $32(11.9 \%)$ and $13(4.8 \%)$ had $16-20$ years and more than 20 years of working experience respectively. The implication of this is that the majority of the respondents have more than five years of working experience. On when the savings account was opened, results obtained from the field survey revealed that $82(30.7 \%)$ opened the innovative savings account less than a year ago; the other $186(69 \%)$ had been operating the savings account for more than a year. The table also shows that $31 \%(n=83)$ have only one source of income, while $69 \%$ have two to three sources of income; some even have four.

Profit from business represents the major source of income for most of the respondents. Table 4 reveals that $50 \%$ $(n=139)$ earn their major source of income from business profit, some of which are in retail/petty trading business, farming, micro-manufacturing such as soap making, shop owners, transporters, private school owners, etc. Forty-eight (17.9\%) are salary earners; some of them are security men, teachers, cleaners, office assistants, clerks, shop attendants, cooks, gardeners, etc. Eighty respondents (29.9\%) earned their income from service fees, some of them are mechanics, vulcanisers, panel beaters, electricians, masons, carpenters, plumbers, lesson teachers, etc. The results also reveal that only $58(21.7 \%)$ respondents save between N500-N1,000 per week, the other 209 (78\%) save between N1,100-N5,000 and more every week. This implies that the government financial inclusion programme is gradually gaining acceptance (N160 exchanges for US\$1 in Nigeria).

With regard to the method of savings before opening the innovative savings account, the majority of the respondents belong to a saving group such as the ROSCA.

Table 4. Savings Characteristics of Respondents

\begin{tabular}{|c|c|c|c|}
\hline Variable & Measuring group & Frequency & Percentage (\%) \\
\hline \multirow[t]{6}{*}{ Years of experience in primary occupation } & $2-5$ years & 62 & 23.2 \\
\hline & $6-10$ years & 105 & 39.3 \\
\hline & $11-15$ years & 55 & 20.5 \\
\hline & $16-20$ years & 32 & 11.9 \\
\hline & More than 20 years & 13 & 4.8 \\
\hline & Total & 267 & 100 \\
\hline \multirow[t]{6}{*}{ When did you open this savings account? } & Less than a 1 year & 82 & 30.7 \\
\hline & One year & 66 & 24.7 \\
\hline & Two years & 65 & 24.4 \\
\hline & Three years & 30 & 11.3 \\
\hline & More than four & 24 & 8.9 \\
\hline & Total & 267 & 100 \\
\hline \multirow[t]{5}{*}{ No. of sources of income } & One & 83 & 31 \\
\hline & Two & 126 & 47 \\
\hline & Three & 30 & 11.2 \\
\hline & More than four & 28 & 10.4 \\
\hline & Total & 267 & 100 \\
\hline \multirow[t]{5}{*}{ Major source of income } & Salary & 48 & 65 \\
\hline & Profit from business & 139 & 17 \\
\hline & Service Fee & 80 & 13 \\
\hline & Other types & 0 & 5 \\
\hline & Total & 267 & 100 \\
\hline \multirow{6}{*}{ Average weekly income } & N500-N1000 & 58 & 21.7 \\
\hline & N1100-N2000 & 59 & 22.0 \\
\hline & N2100-N3500 & 56 & 20.9 \\
\hline & N3600-N5000 and more & 76 & 28.4 \\
\hline & Not able to determine the amount & 18 & 6.0 \\
\hline & Total & 267 & 100 \\
\hline
\end{tabular}




\begin{tabular}{|c|c|c|c|}
\hline \multirow[t]{5}{*}{ Method of savings before now } & Daily money collector & 78 & 29.2 \\
\hline & Savings group & 118 & 44.1 \\
\hline & $\begin{array}{l}\text { Regular deposit to respectable member of the } \\
\text { community }\end{array}$ & 20 & 7.4 \\
\hline & In the house/farm & 51 & 19.3 \\
\hline & Total & 267 & 100 \\
\hline \multirow{5}{*}{$\begin{array}{l}\text { How frequent do you save now after opening this } \\
\text { account? }\end{array}$} & Daily & 120 & 44.9 \\
\hline & Weekly & 60 & 22.4 \\
\hline & Every two weeks & 40 & 14.9 \\
\hline & Monthly & 47 & 17.6 \\
\hline & Total & 267 & 100 \\
\hline \multirow[t]{5}{*}{ Why do you save? } & To expand my business & 87 & 32.5 \\
\hline & To be able to meet an emergency & 58 & 21.7 \\
\hline & For the future of the children & 62 & 23.2 \\
\hline & To be in control & 60 & 22.4 \\
\hline & Total & 267 & 100 \\
\hline \multirow[t]{5}{*}{ Why did you open this savings account with the bank? } & It is convenient for me & 126 & 47.1 \\
\hline & For safety of my money & 56 & 20.9 \\
\hline & I want more safety & 45 & 16.8 \\
\hline & To access loans & 40 & 14.9 \\
\hline & Total & 267 & 100 \\
\hline \multirow[t]{5}{*}{ Who introduced this savings account to you? } & Friend/colleagues & 50 & 18.7 \\
\hline & The bank staff & 59 & 22.0 \\
\hline & Savings group member & 111 & 41.5 \\
\hline & Through an advertisement & 47 & 17.6 \\
\hline & Total & 267 & 100 \\
\hline
\end{tabular}

Source: Researcher's analysis of field survey, 2013.

Table 4 reveals that 118 (44.1\%) respondents belong to a saving group and that is how they saved before now. Some also saved with a local daily money collector, while others saved with respected members of the community and others simply kept their money at home or on their farms. In terms of how frequent they save now 120 (44.9\%) save daily. This implies that they found the innovative savings accounts convenient; others save twice a week, weekly and monthly. In order to know why they opened a savings account, the majority $(n=87 ; 32.55 \%)$ revealed that they want to use the money saved to expand their businesses, others said they want to use money saved to meet emergency needs and buffer shocks, some said to be in control of their lives, while others say to meet children's schooling expenses.

On why they opened this particular savings account, the majority reported it was convenient, some reported they wanted to save more, some reported for safety of the money, while others reported to be able to access bank loans. Lastly, on who introduced this savings account to them, 111 (41.5\%) respondents reported their savings group members; this buttresses why the formal banking institutions in Nigeria need to connect with informal financial service providers. Informal financial service providers are more able to convince their members to open accounts with the bank because they trust their judgement.

\subsection{Hypotheses Testing}

\subsubsection{Hypothesis One}

To test if the savings rate has not changed significantly after the introduction of innovative savings products in the Nigerian financial system a paired sample t-test was used. The results obtained are shown in Tables 5 and 6 below.

Table 5. Paired Sample Statistics

\begin{tabular}{|lc|c|c|c|c|}
\hline & & Mean & N & Std. Deviation & Std. Error Mean \\
\hline \multirow{2}{*}{ Pair 1 } & Weekly save before & 1531.92 & 267 & 1764.011 & 107.956 \\
& Weekly save now & 3903.37 & 267 & 4674.313 & 286.063 \\
\hline
\end{tabular}

Source: Authors computation, 2015 
Table 6. Paired Sample Test

\begin{tabular}{|c|c|c|c|c|c|c|c|c|}
\hline & \multicolumn{5}{|c|}{ Paired Differences } & \multirow{3}{*}{$\mathrm{T}$} & \multirow{3}{*}{ Df } & \multirow{3}{*}{$\begin{array}{l}\text { Sig. }(2- \\
\text { tailed) }\end{array}$} \\
\hline & \multirow{2}{*}{ Mean } & \multirow{2}{*}{$\begin{array}{c}\text { Std. } \\
\text { Deviation }\end{array}$} & \multirow{2}{*}{$\begin{array}{l}\text { Std. Error } \\
\text { Mean }\end{array}$} & \multicolumn{2}{|c|}{$\begin{array}{l}\text { 95\% Confidence Interval of the } \\
\text { Difference }\end{array}$} & & & \\
\hline & & & & Lower & Upper & & & \\
\hline $\begin{array}{l}\text { Pair Weekly save at start - weekly } \\
1\end{array}$ & 2371.45 & 4474.92 & 273.86 & 1832.24 & 2910.66 & 8.659 & 266 & .000 \\
\hline
\end{tabular}

Source: Authors computation, 2015

Tables 5 and 6 above show the results of the paired sample t-test conducted to ascertain if there is a significant difference in the savings rate of the respondents as a result of the usage of innovative savings products. The results obtained show that there is a statistically significant difference between weekly saving before usage of the innovative savings product and weekly savings now. Weekly savings before the introduction of the innovative savings product is $\mathrm{N} 1,531.92$, while the mean of weekly savings after the introduction of the innovative savings product is $N 3,903.37$. With a t-value of 8.659, $p<.0005$ (two-tailed), the mean difference is N2,371 with a 95\% confidence level. The eta-squared statistic calculated (.21) indicates a large effect size. The study therefore accepted the alternative hypothesis that the savings rate has changed significantly after the introduction of the innovative savings product in the Nigerian financial system.

\subsubsection{Hypothesis Two}

There is no significant reduction in the level of household poverty in Nigeria. below.

This hypothesis was tested using multiple regression analysis. The results of the regression are shown in Table 7

Table 7. Innovative Saving Products and Poverty Alleviation

\begin{tabular}{|c|c|c|c|c|c|}
\hline \multirow{2}{*}{ Model } & \multicolumn{2}{|c|}{ Unstandardized Coefficients } & \multirow{2}{*}{$\begin{array}{c}\text { Standardized Coefficients } \\
\text { Beta }\end{array}$} & \multirow{2}{*}{$\mathrm{T}$} & \multirow{2}{*}{ Sig. } \\
\hline & B & Std. Error & & & \\
\hline (Constant) & .95 & 27 & & 3.52 & .003 \\
\hline Type of location (urban) & .30 & .18 & .08 & 1.67 & .009 \\
\hline Sources of income (2 or more) & .22 & .11 & .14 & 2.02 & .001 \\
\hline E-susu & 36.43 & 15.94 & 1.10 & 2.29 & .007 \\
\hline Firstlnstant & 211.76 & 133.08 & .186 & 1.63 & .095 \\
\hline GT e-account & -157.28 & 147.53 & -.011 & -1.07 & .433 \\
\hline Microfinance Bank Savings Account & -131.21 & 103.46 & -.19 & -1.27 & .133 \\
\hline Savings growth rate & 1.66 & .80 & .022 & 2.07 & .083 \\
\hline Reduced debt obligations & -653.35 & 295.64 & -.23 & -2.20 & .028 \\
\hline Number in household (less than five) & 408.30 & 243.38 & .12 & 1.68 & .095 \\
\hline Level of education (secondary education) & 690.39 & 365.92 & .11 & 1.89 & .004 \\
\hline
\end{tabular}

a. Dependent Variable: Changes in household income $R^{2}=52, F=14.573, p$ value $=.000$.

Source: Authors Computation, 2015

The results of the regression show that type of location (urban), sources of income (more than 2), type of savings account (E-susu, and Firstlnstant), savings growth rate, number in household (less than five), level of education (secondary education) all have a positive correlation with change in household income. This implies that the higher the increase in all of these variables, the higher the increase in household income. As the savings rate continues to grow as a result of the innovative savings product, as respondents' level of education improves, as the number of sources of income increases, and as different types of innovative savings products (E-susu and Firstlnstant) are embraced by more people, household income will continue to grow. The results also show that saving products (GT e-account and MFI savings account) have a 
negative measure of impact on changes in household income; the results obtained for the two products are also not statistically significant. The results also show that reduced debt obligation has a negative impact on household income and it is statistically significant at $5 \%$. This implies that as householders reduce their debt obligation they are further impoverished, which suggests dependence on borrowed funds even to meet consumption needs. All the results obtained are statistically significant at $5 \%$ and $10 \%$ significant levels, except for type of savings account (GT e-account and MFIs savings account). The $\mathrm{R}^{2}$ of $52 \%$ shows that the explanatory variables explained $52 \%$ of the variation in the dependent variable. The F-test of $14.573(0.000)$ shows the overall significance of the model.

Table 8. Innovative Savings Product and Business Enterprise Development

\begin{tabular}{|c|c|c|c|c|c|c|}
\hline \multicolumn{7}{|c|}{ Coefficientsa } \\
\hline \multirow{2}{*}{\multicolumn{2}{|c|}{ Model }} & \multicolumn{2}{|c|}{ Unstandardized Coefficients } & \multirow{2}{*}{$\frac{\text { Standardized Coefficients }}{\text { Beta }}$} & \multirow{2}{*}{$\mathrm{T}$} & \multirow{2}{*}{ Sig. } \\
\hline & & B & Std. Error & & & \\
\hline & (Constant) & 4805.98 & 2137.89 & & 2.248 & .002 \\
\hline & E-susu & 568.85 & 190.26 & .126 & 2.989 & .006 \\
\hline & Firstlnstant & 851.20 & 1375.72 & .061 & .619 & .537 \\
\hline & GT e-account & -3221.96 & 1823.70 & -.190 & -1.067 & .158 \\
\hline & Microfinance Bank Savings Account & 4327.66 & 1209.24 & .366 & 3.579 & .001 \\
\hline & Savings growth & 276.86 & 105.12 & .043 & 2.633 & .018 \\
\hline & Years in prior occupation & 22.76 & 10.59 & .016 & 2.149 & .002 \\
\hline & Acquired more fixed assets & 199.65 & 75.63 & .041 & 2.639 & .003 \\
\hline & Increase business outlet & -633.50 & 290.98 & -.152 & -2.177 & .030 \\
\hline & Increase Household Income & 323.11 & 106.44 & 023 & 3.035 & .011 \\
\hline
\end{tabular}

aDependent Variable: Increase in business revenue $\mathrm{R}^{2}-45 \%$, F-test $=16.035, \mathrm{p}$ value $=.000$.

Source: Authors computation, 2015

Table 8 - Hypothesis 3 - Innovative savings products do not have a significant impact on business enterprise development.

The result of the regression analysis for hypothesis 3 is shown in Table 8 above. The results obtained show that the savings growth rate, type of savings account (E-susu and MFI savings account), years of experience in business, increase in fixed assets, and increase in household income all have a positive correlation with increase in business revenue. This implies that the higher the increase in all of these variables, the higher the increase in enterprise business revenue. The results also show that as the entrepreneur opens more lines of business arbitrarily, business revenue will decrease significantly. Type of savings account (GT e-account and Firstlnstant) is not statistically significant, this may imply that such savings product is not compatible with entrepreneurial activities; all other results obtained are statistically significant at $5 \%$ and $10 \%$ significant levels. The $\mathrm{R}^{2}$ of $45 \%$ shows the explanatory variables explained $45 \%$ of the variation in the dependent variable. The F-test of $16.035(0.000)$ shows the overall significance of the model.

\section{Conclusion and Recommendations}

The study examined the impact of recently introduced innovative savings products by some deposit taking banks in Nigeria on the savings rate, welfare and enterprise development drive of savers. The results showed that the weekly savings rate has increased by $160 \%$ and that the use of savings products has a significant impact on the welfare and enterprise development drive of savers, thereby alleviating poverty among low-income earners. This implies that the financial inclusion programme by the federal government has the potential to alleviate poverty and should be intensified. The study shows that access to savings, which are the beginning of access to other formal financial services, enhanced household welfare and enterprise development drive. The study, therefore, concludes that enhancing access to savings using innovative savings products has a high likelihood of reducing poverty both in urban and rural areas in Nigeria. The policy implication is that the federal government of Nigeria and financial institutions in the country should work together to drive financial inclusion in the country. Appropriate technology and legislation should be deployed to encourage the deposit money bank in the country to develop more innovative financial products that would be easily accessible to lowincome earners. Financial institutions should be encouraged to drive rural savings mobilization through agent mobile banks. The following are other recommendations based on the findings: 
- Formal financial institutions in the country should connect with informal financial service providers as they have a way of convincing their clients of how and where to save.

- Most of the innovative financial products require functional infrastructure to operate effectively, the study thereby implores stakeholders to invest more in infrastructure development such as energy.

- The banks and various other government agencies should develop financial literacy programmes and enlighten local communities on the use of banks and the financial products available at the banks.

- Formal financial institutions should show more commitment in driving financial inclusion programmes; their commitment will convince more people to use banks rather than keep money at home.

- Commitment savings should be tied to loan approval. That is borrowers should be encouraged to save up to a certain amount and then be extended a loan up to as much as twice or thrice the amount they have been able to save.

\section{References}

Agosin, M., 1999, "Private finance for development: analytical underpinnings and policy issues", Office of Development Studies, Bureau for Development Policy. United Nations Development Programme.

Ainslie, G., 1992, Picoeconomics, Cambridge University Press, Cambridge.

Ashraf, N., D. S. Karlan and W. Yin, 2006, "Tying Odysseus to the mast: evidence from a commitment savings product in the Philippines", Quarterly Journal of Economics, Vol. 121, No. 2, pp. 635-672. Available online at: http://www.assortis.com/news letter/download/mcf002032.pdf?

Ashraf, N., N. Gons, D. S. Karlan and W. Yin, 2003, "A review of commitment savings products in developing countries", Economic and Research Working Paper Series No. 45, Asian Development Bank. Available online at: http://www.adb.org/Documents/ERD/ Workings_Papers/wp045.pdf

Brau, J. C. and G. M. Woller, 2004, "Microfinance: a comprehensive review of the existing literature", Journal of Entrepreneurial Finance and Business Ventures, Vol. 9, No. 1, pp. 1-26.

Buchenau, J., 1999. "Innovative products and adaptations for rural finance". Available online at: http://www.basis.wisc.edu/rfc/ documents/theme_products.pdf

Count, A. and P. Meriweather, 2008, "New frontiers in microsavings", Grameen Foundation publication. Available online at: www.micro financegateway.org/gm/document

Deaton, A., 1989, "Savings in developing countries: theory and review". Proceedings of the World Bank, Annual Conference on Development Economics. Washington, D.C.

Dupas, P. and J. Robinson, 2013, "Why don't the poor save more? Evidence from health savings experiments", American Economic Review, Vol. 103, No. 4, pp. 1138-1171.

Fasoranti, M. M., 2007, "The influence of rural savings mobilization on economic development of rural dwellers: a study of Akoko region in Ondo State", International Business Management, Vol. 1, No. 2, pp. 20-23.

Friedman, M., 1954, A Theory of the Consumption Function. Princeton University Press, Princeton.

Hossain, M., 1988. Credit for Alleviation of Rural Poverty: The Grameen Bank in Bangladesh. IFPRI Research Report 65. International Food Policy Research Institute, Washington, D.C.

Keynes, J. M., 1936, General Theory of Employment, Invest and Money, MacMillan Company Ltd., London.

Ladipo, M. (2008). "Enhancing financial innovation and access. Results of survey of Nigerian adult population", pp. 2-8.

Laibson, D., 1996, "Hyperbolic discount functions, undersaving and savings policy". NBER Working Paper 5635, June 1996.

Laibson, D., 1997, "Golden eggs and hyperbolic discounting", The Quarterly Journal of Economics, Vol. 112, No. 2, pp. 443-478.

Lariviere, S. and F. Martin, 1998, "Innovations in rural microfinance: the challenge of sustainability and outreach". Paper presented at the International Workshop on Innovations in Microfinance for the Rural Poor, 9-13 November, ACCRA, Ghana. Cited in Llanto, G. M. and R. Fukui, 2005, "Innovations in Microfinance in Southeast Asia", Philippine Institute of Development Studies (PIDS) Research Paper Series, No. 2006 - 02. Available online at: http://dirp3.pids.gov.ph/ris/rps/pidsrp0602.pdf http://dirp4.pids.gov. ph/ris/pdf/pidsdps0311.pdf

Lowenstein, G. and D. Prelec, 1992, "Anomalies in inter-temporal choice: evidence and an interpretation", Quarterly Journal of Economics, Vol. 107, No. 2, pp. 573-597.

Lowenstein, G. and R. H. Thaler, 1989, "Anomalies: intertemporal choice", Journal of Economic Perspectives, Vol. 3, No. 4, pp. 181-193.

Modigliani, F., 1966, "The life-cycle hypothesis of saving, the demand for wealth, and the supply of capital", Social Research, Vol. 33, pp. 160-217.

Morduch, J., 1999, "The Microfinance Promise", Journal of Economic Literature, Vol. 37, No. 4, pp. 1569-1614.

Nwanchukwu, T. E. and P. Odigie, 2009, "What drives private savings in Nigeria?" A Paper Presented at the Centre for the Study of African Economies (CSAE) Conference, University of Oxford, March 2009. Available online at: www.csae.ox.ac.uk/conferences/ 2009-EDiA/.../502-Nwachukwu.pdf

O'Donahue, T. and M. Rabin, 1999, "Doing it now or doing it later", The American Economic Review, Vol. 89, No. 1, pp. 103-121.

Rutherford, S. et al., 1999, "Savings and the poor: the methods, use and impact of savings by the poor of East Africa", Report prepared 
for Micro-Save-Africa, May 1999.

Sanusi, J. O., 2002, "Savings management in developing countries", An address delivered at the Banking and Financial Services Symposium, organized by the Commonwealth Business Council, London, 3-4th July, 2002. Available online at: www.cenbank.org Shipton, P., 1992, "The Rope and the box: group savings in the Gambia", Working paper.

Smith, A., 1776, An Enquiry into the Nature and Causes of the Wealth of Nations, University of Glasgow, Glasgow.

Thaler, R., 1992, The Winner's Curse: Paradoxes and Anomalies of Economic Life, Princeton University Press, Princeton.

Umoh, O. J., 2003, "An empirical investigation of the determinants of aggregate national savings in Nigeria", Journal of Monetary and Economic Integration, Vol. 3, No. 2, pp. 113-132.

Uremadu, S. O., 2006, "The impact of real interest rate on savings Mobilization in Nigeria". An unpublished PhD Thesis proposal submitted to the Department of Banking and Finance, University of Nigeria, Enugu campus.

Watson, J. and J. Everett, 1999. "Small business failure rate: choice of definition and industry effects", International Small Business Journal, Vol. 17, pp. 123-129. 